\title{
Energy savings and economic benefits of transition towards efficient lighting in residential buildings in Cameroon
}

\author{
K. E. Enongene* ${ }^{1}$, P. Murray $^{2}$, J. Holland ${ }^{3}$ and F. H. Abanda ${ }^{4}$ \\ ${ }^{1,3}$ Institute of Agriculture and Environment, College of Sciences, Massey University, Palmerston \\ North 4410, New Zealand \\ ${ }^{2}$ School of Engineering and Advanced Technology, Massey University, Palmerston North \\ 4410, New Zealand \\ ${ }^{4}$ Oxford Institute for Sustainable Development, School of the Built Environment, Oxford Brookes \\ University, Oxford, OX3 OBP, UK
}

\section{* Corresponding author: $\underline{\text { K.Enongene@,massey.ac.nz }}$}

\begin{abstract}
Lighting accounts for over $20 \%$ of electricity use in the residential sector of Cameroon. Due to the unreliable and inadequate energy supply in the country, there is a need for the efficient utilization of the available energy. This paper presents the current different technologies used for artificial lighting including the economic and environmental benefits associated with a switch from incandescent lighting to compact fluorescent lamp (CFL) and light emitting diode (LED) in residential dwellings in Buea, Cameroon. The study employed a survey of 100 residential dwellings in Buea. Results of the survey revealed that artificial lighting in dwellings is achieved through the use of the following technologies: incandescent lamps, CFLs and fluorescent tubes. The economic assessment for the substitution of incandescent lamps with CFL and LED considering an average daily lighting duration of six hours was also conducted using the net present value (NPV), benefit cost ratio (BCR), the simple payback period (PBP) and a life cycle cost analysis (LCC). The economic assessment revealed an NPV that ranges from $\$ 47$ to $\$ 282.02$, a BCR of 1.84 and a PBP of 0.17 year for the substitution of current incandescent lamps in dwellings with CFL while the substitution of incandescent lamps with LED revealed an NPV of the range $\$ 89.14$ to $\$ 370$, a BCR of 3.18 and a PBP of 1.92 years. The LED and incandescent technologies emerged with the lowest and highest LCC respectively. Substituting incandescent lamps with CFL and LED results in a reduction in lighting related greenhouse gas (GHG) emissions from dwellings by $66.6 \%$ and $83.3 \%$ respectively. From the results, a transition towards efficient lighting in the residential sector of Cameroon possesses great economic and environmental benefits. There is need for the government of Cameroon to expedite the uptake of LED through the formulation and implementation of favourable policies.
\end{abstract}

Key words: Energy, efficient lighting, Cameroon, light emitting diodes, residential buildings. 
The emissions of greenhouse gases (GHGs) from anthropogenic and natural activities since the onset of the industrial age have led to their increased concentration in the atmosphere. The absorption of radiations by these gases alters the amount of solar radiation reaching the earth and the amount of infrared radiation that is absorbed into space. The result is an energy imbalance in the atmosphere culminating in cooling or warming of the climate depending on the radiating forcing being negative or positive respectively (Forster et al., 2007). Global climate change has in recent times raised serious global concerns and is currently one of the contemporary world's most worrisome problems.

The built environment is recognised for its high energy use and the relative share of total energy consumed for heating and operating buildings is constantly on the rise (Raatikainen et al., 2016). While the building sector provides facilities for human needs and benefits to the society at large, it has had detrimental impacts on the environment over the last decade (Zuo $\&$ Zhao, 2014). The consumption of energy by this sector is not without environmental impacts (Ürge-Vorsatz, 2013) and implications on security of energy supply. While all stages of a building's life cycle including construction and demolition generates GHG emissions, the operational phase of buildings accounts for over $80-90 \%$ of emissions, emanating from energy use for heating, lighting, cooling, ventilation and appliances (UNEP, 2012). The operational energy of buildings is affected by the energy efficiency of the buildings and their systems, as well as the behaviour of the occupants (Stephan \& Stephan, 2016; Abanda \& Cabeza 2015). As reported in Lucon et al. (2014), the global building sector in 2010 accounted for about $32 \%$ of final energy use and over $8.8 \mathrm{GtCO}_{2}$ emissions, with energy demand projected to double by mid-century. According to studies by de la Rue du Can et al. (2015), direct and indirect emissions emanating from energy use in the global building sector accounts for $31 \%$ of global carbon dioxide $\left(\mathrm{CO}_{2}\right)$ emissions originating from the combustion of fuel for electricity production and heat to end-use sectors. The residential sector accounts for $27 \%$ and $17 \%$ of global energy consumption and $\mathrm{CO}_{2}$ emissions respectively (Nejat et al., 2015).

Cameroon's residential sector constitutes the second highest electric energy consumer after the industrial sector, accounting for 30\% of total energy consumed (European Union Energy Initiative Partnership Dialogue Facility, 2014). This sector has grown tremendously, with strong evidence revealed through the housing boom and public construction sites observed in recent times in the country. With an envisaged projected increase in population from the current 23.34 million to 32.94 million in 2030 (United Nations, 2015), there is likely to be an increased pressure on built environment services in Cameroon which will culminate in an increase in energy demand from the residential sector. This increase in energy demand will further put pressure on the energy infrastructure of the country which according to Nfah and Ngundam (2009) is inadequate and unreliable. The envisaged increase in energy demand and consumption in the country is likely to be accompanied by an increase in GHG emissions based on the claims of Abanda (2012) that the amount of $\mathrm{CO}_{2}$ emission associated with energy consumption in Cameroon has since the 1980s been on the rise.

During the launch of the Global Alliance for Buildings and Construction at the $21^{\text {st }}$ session of the Conference of Parties (COP) in Paris, the likely positive effects of energy efficiency in buildings was at the centre of focus (Global Buildings Performance Network, 2015). Energy inefficiency in buildings results to the excessive consumption of energy which often culminates in high energy cost in low-income households. The excessive energy consumption also puts pressure on the grid electricity supply which is often generated from conventional 
fuel associated with greenhouse gas emission that drives global climate change. As the power crisis problem in developing countries exacerbates, culminating in an increase in the gap between energy demand and supply, measures are adopted to resolve the power shortage problem through the efficient use of the available power (Aman et al., 2013). While the improvement of the behaviour of building occupants results to energy savings (Ouyang \& Hokao, 2009), the adoption of more energy efficient technologies in residential buildings equally have an important role to play. Reducing energy consumption in buildings through the implementation of cost effective energy efficient measures translates not only into a reduction in energy bills of households, but as well reduces GHG emissions (AlAjmi et al., 2016; Girod et al., 2014).

Studies conducted by Batih \& Sorapipatana (2016) in Indonesia revealed that lamps employed in indoor lighting are among the appliances with the greatest potentials for electrical energy reduction in the built environment. Nallamothu et al. (2015) noted that the energy efficiency associated with the use of high efficient LED bulbs is over $57.5 \%$. A strategic area with potentials for energy savings and reduction in peak power demand in the residential sector of Cameroon is lighting which is still dominated by the use of incandescent lamps (SIE, 2012). Lighting in 2007 and 2010 respectively represented 30\% and 20\% household electricity use in the country. Research related to the uptake of energy efficient lighting technologies have been stepped up in several countries. For instance, Khorasanizadeh et al. (2015) investigated the energy and economic benefits associated with the transition towards LED lighting in the residential sector of Malaysia. Mins \& Mills (1997) studied the prospects and problems of energy efficient lighting in China, MartínezMontejo \& Sheinbaum-Pardo (2016) analysed among others the impacts of minimum energy efficiency standards of lighting product on residential electricity consumption and carbon dioxide emissions in Mexico, while Figueroa (2016) assessed the drivers of uptake and willingness to pay for an efficient lighting technology in the residential sector of Kenya. While studies about efficient lighting have been conducted in other countries, such studies have not been conducted for Cameroon. An extensive search of peer-reviewed articles about studies related to transition towards efficient lighting in Cameroon in popular databases such as Google Scholar, Science Direct and Emerald yielded no significant results. Studies conducted in other countries cannot be adapted to Cameroon due to differences in local circumstances. For example, housing types in Cameroon may not be the same like the housing types in the Middle East and Europe due to cultural differences and occupant behaviour. A study on the transition towards efficient lighting is therefore necessary for Cameroon as it would assist the government and other stakeholders in the adoption of appropriate strategies that would guarantee a transition towards efficient lighting and this constitutes the motivation based on which this study was carried out.

The purpose of this study is to investigate the benefits for the transition towards efficient lighting using light emitting diodes and compact fluorescent lamps in the residential sector of Cameroon as well as the possible factors that could affect the adoption of LEDs in the country, using the town of Buea as a case study.

The objectives are to:

- investigate the possible factors that affects the transition towards efficient lighting in the residential sector of the country;

- determine the economic and environmental benefits associated with the transition towards efficient lighting in the residential sector; 
- assess the possible impacts of a government policy on the economic benefits of transition towards LED lighting.

To achieve the above objectives, a research methodology has been established which draws from the scarcity of secondary data on lighting technologies used in residential dwellings in Cameroon. The main research method included: a survey of residential dwellings in the case study area with a questionnaire to obtain the required data for the study-existing lighting systems; and an analysis of the economic and environmental potentials associated with a transition towards efficient lighting in dwellings.

\section{A review of Cameroon electricity sector and residential buildings}

\subsection{Cameroon electricity sector}

Cameroon has an enormous energy potential. According to Nfah and Ngundam (2009), the country possesses the second largest hydroelectric potential (294 TWh) in Africa after the Democratic Republic of Congo estimated at 1000 TWh. However, only $5.5 \%$ of the technically-feasible capacity (115 TWh/year) has been developed. In Cameroon, electricity is generated from three hydroelectric power stations (Edea, Song Loulou and Ladgo) and nine thermal power plants (Fotsing et al., 2014). In 2010, Cameroon had an installed hydroelectric power capacity of $729 \mathrm{MW}$ while it had $776 \mathrm{MW}$ installed capacity of thermal power plants (diesel and natural gas) owned by both AES SONEL and independent power producers (Ayompe \& Duffy, 2014). Cameroon's electricity sector is currently poorly developed and this has slowed down socio-economic development in the country. The sector faces both structural and technical challenges, compounded by the low electrification rate in the country (African Development Fund, 2009). Out of over 14000 localities, only 3000 are electrified giving a national electrification rate of $22 \%$. This low rate of electrification is a major setback for the production of goods and services since energy constitutes an important factor of production. In a nut shell, the Cameroon electricity sector faces an annual deficit between the electric power demand and what the system is capable of supplying. This deficit is due to very high rate of losses incurred in the process of generation, transmission and distribution of electricity (European Union Energy Initiative Partnership Dialogue Facility, 2014).

Cameroon's electricity demand in 2012 was estimated at $3710 \mathrm{GWh}$ (European Union Energy Initiative Partnership Dialogue Facility, 2014). Electricity demand from low user and medium user consumer in Cameroon is on the rise. On an annual basis, the demand of electricity from these groups of consumers increases by an average of $6 \%$ with an estimated demand of $4700 \mathrm{GWh}$ and $7600 \mathrm{GWh}$ in 2015 and 2025 respectively (Government of Cameroon, 2010). On the other hand, industrial demand which is mainly determined by the energy requirements of the aluminium industry was estimated at $1315 \mathrm{GWh}$ in 2010 with its demand estimated to triple by 2015 . Based on recent studies conducted by the European Union Energy Initiative Partnership Dialogue Facility (2014), growth in electricity demand in the industry, tertiary buildings and residential sectors by 2025 against the 2012 benchmark is forecasted at $109 \%, 55 \%$ and $79 \%$ respectively. The residential sector in the country is characterised by the use of obsolete, inefficient and second handed appliances (Enongene et al., 2016; Manjia et al., 2015; Kenfack et al., 2011) which results to increasing energy consumption and demand from this sector.

The supply of electricity in Cameroon is done through a number of transmission lines. In 2010, the power company in the country operated three different transmission grids: the southern interconnected grid (SIG); the northern interconnected grid (NIG); and the eastern 
interconnected grid (EIG) through which all the electricity generated in the country is transmitted and distributed to the customers (Ayompe \& Duffy, 2014). The southern interconnected grid covers six regions in the country: Centre, Littoral, West, Northwest, Southwest and South while the northern interconnected grid and the eastern interconnected grid covers three (Adamawa, North and Far North) regions and one (East) region respectively (Fotsing et al., 2014).

The reliability of the supply of electricity, which plays an unequivocal role to the growth of any modern economy by virtue of its diverse end use, is poor in Cameroon. The principal source of electricity in Cameroon is the hydroelectric system which suffers from under development (European Union Energy Initiative Partnership Dialogue Facility, 2014). The absence of effective strategies that will guarantee diversification of electricity generation sources exacerbates the situation. The results are frequent power cuts mostly experienced during the drier months of January to June (Nfah \& Ngundam, 2009). During this period of seasonal drought, the energy generated by back-up thermal plants is usually insufficient to meet demand and the rationing of electricity does not guarantee the day-to-day operation of industries especially those connected to networks of low voltage.

\subsection{Types of residential buildings in Cameroon}

Building energy performance is influenced by a number of factors; climate, building size, building operation and maintenance, efficient technologies, and human behaviour (Li et al., 2014; Abanda \& Cabeza 2015). Hence, the size of residential buildings constitutes an important component that depicts energy consumption. The sizes and characteristics of houses investigated in this study will be examined. In Cameroon, the Ministry of Housing and Urban Development classifies residential buildings in the country into six different categories (Manjia et al., 2015) based on the components of the building as shown in Table 1. The environmental and economic assessments conducted in this study will be based on the dwellings presented in Table 1.

Table 1: Category of residential buildings in Cameroon

\begin{tabular}{|c|c|c|c|c|c|}
\hline Type & Component & Quantity & $\begin{array}{l}\text { Minimal } \\
\text { area }\left(\mathbf{m}^{2}\right)\end{array}$ & $\begin{array}{c}\text { Entire Minimal } \\
\text { area }\left(\mathbf{m}^{2}\right)\end{array}$ & $\begin{array}{l}\text { Average number of } \\
\text { incandescent bulbs }\end{array}$ \\
\hline \multirow{4}{*}{$\mathrm{T} 1$} & bedroom & 1 & 12 & \multirow{4}{*}{20} & \multirow{4}{*}{ 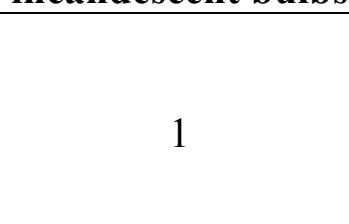 } \\
\hline & kitchen & 1 & 3 & & \\
\hline & Toilet & 1 & 3 & & \\
\hline & corridor & 1 & 2 & & \\
\hline \multirow{5}{*}{$\mathrm{T} 2$} & $\begin{array}{l}\text { Living room }+ \\
\text { Dining room }\end{array}$ & 1 & 10 & \multirow{5}{*}{32} & \multirow{5}{*}{3} \\
\hline & bedroom & 1 & 12 & & \\
\hline & kitchen & 1 & 3 & & \\
\hline & Toilet & 1 & 5 & & \\
\hline & corridor & 1 & 2 & & \\
\hline \multirow{5}{*}{$\mathrm{T} 3$} & $\begin{array}{l}\text { living room }+ \\
\text { Dining room }\end{array}$ & 1 & 20 & \multirow{5}{*}{62} & \multirow{5}{*}{4} \\
\hline & bedroom & 2 & 12 & & \\
\hline & kitchen & 1 & 10 & & \\
\hline & Toilet & 1 & 5 & & \\
\hline & corridor & 1 & 3 & & \\
\hline
\end{tabular}




\begin{tabular}{|c|c|c|c|c|c|}
\hline \multirow{5}{*}{$\mathrm{T} 4$} & $\begin{array}{l}\text { living room }+ \\
\text { Dining room }\end{array}$ & 1 & 25 & \multirow{5}{*}{89} & \multirow{5}{*}{5} \\
\hline & bedroom & 3 & 12 & & \\
\hline & kitchen & 1 & 10 & & \\
\hline & Toilet & 2 & 5 & & \\
\hline & corridor & 1 & 8 & & \\
\hline \multirow{5}{*}{ T5 } & $\begin{array}{l}\text { living room }+ \\
\text { Dining room }\end{array}$ & 1 & 30 & \multirow{5}{*}{106} & \multirow{5}{*}{6} \\
\hline & bedroom & 4 & 12 & & \\
\hline & kitchen & 1 & 10 & & \\
\hline & Toilet & 2 & 5 & & \\
\hline & corridor & 1 & 8 & & \\
\hline \multirow{5}{*}{ T6 } & $\begin{array}{l}\text { living room }+ \\
\text { Dining room }\end{array}$ & 1 & 35 & \multirow{5}{*}{130} & \multirow{5}{*}{4} \\
\hline & bedroom & 5 & 12 & & \\
\hline & kitchen & 1 & 10 & & \\
\hline & Toilet & 3 & 5 & & \\
\hline & corridor & 1 & 10 & & \\
\hline
\end{tabular}

\section{An overview of lighting technologies}

\subsection{Evolution and trend in the use of lighting technologies}

Electricity became available in industrial areas at the end of the $19^{\text {th }}$ Century and the lighting technology was developed for using electricity as an energy source. Incandescent light bulb was the first lighting technology that emerged (Wen \& Agogino, 2008). Incandescent lighting function is based on the flow of electric current through a metal filament in the bulb and the resistance of the filament generates heat that causes the metal to glow and emit a yellowish light. Fluorescent lamps on the other hand were established after the Second World War (Schanda, 2005) and function on the basis that materials captivate radiation at one wavelength and re-emit radiation in a longer wavelength (Luo, 2011). Fluorescent lamps were further developed to compact fluorescent lamps (CFLs) which are more efficient than the former albeit they both use the same technology (Silveira \& Chang, 2011). Light emitting diodes (LED) were first fabricated in the mid-1960s using Gallium arsenide phosphide (Wen \& Agogino, 2008) and the technology entails a quantum method for converting electrical energy directly into light (Sebitosi \& Pillay, 2007). Unlike in the other lighting technologies, generation of light in LEDs is based on the principle of electroluminescence, in which electrons and holes recombine in a semi conductor diode releasing energy in the form of photons (Luo, 2011).

For close to a century, incandescent bulbs emerged as the main lighting technology for residential buildings due to the visual comfort. The main attempt to introduce fluorescent bulbs in residential lighting in the 1960s failed (Menanteau \& Lefebvre, 2000). This was despite the superior technical qualities; a lifetime 5-10 times longer than incandescent bulbs, their luminous efficiency five times greater than that of incandescent bulbs and their ability to give off very little heat. This failure was associated with the consumer's perception of the bright light emitted by the fluorescent bulb as being cold and disappointing compared to the warm light emitted by incandescent bulbs, which was associated with visual comfort 
(Menanteau \& Lefebvre, 2000). More so to this visual discomfort, the uptake of fluorescent tube required a change in the domestic light fittings since the fluorescent tubes were not compatible with the existing installation at the time and this served as a disincentive for their uptake.

A number of factors influence the adoption of lighting technologies. In their study, Min et al. (2014) revealed that the five most important bulb characteristics based on which consumers make their choice include: price, energy use, colour, lifetime and brightness. Both LED and CFL stand out as more efficient lighting technologies. Compared to incandescent bulbs, they possess a longer life span and their use decreases the overall light energy consumption (Hicks et al., 2015). However, as reported by Wada et al. (2012), the low capital cost of incandescent bulbs acts as a disincentive for consumers to use the more expensive and more energy efficient lighting technologies such as compact fluorescent bulbs and light emitting diodes. According to Wada et al. (2012), this low capital cost of incandescent bulbs accounts for the reason why they are the dominant lighting technology used in many countries. From a cost perspective, it can be argued that consumers who prefer incandescent bulb to other efficient lighting technologies make their preference based on the capital cost with little or no knowledge of the operating cost of the technologies. This is confirmed by the study of Min et al. (2014) which demonstrated the willingness of a consumer to pay $\$ 0.14$ and $\$ 0.46$ more for a bulb for an increase in lifetime and decrease in power rating respectively. Some consumers as well have a stronger preference for incandescent bulbs over CFL on the grounds that the latter contains toxic materials like Mercury (Min et al., 2014).

The skyrocketing of energy prices globally at the end of the $20^{\text {th }}$ century called for innovation and adoption of energy efficient technologies. The innovation in the incandescent technology led to the introduction of the halogen cycle which increased the working life of the bulb and the luminous efficiency from 15 to $201 \mathrm{~m} / \mathrm{W}$ (Menanteau \& Lefebvre, 2000). With a luminous efficiency that exceeded $601 \mathrm{~m} / \mathrm{W}$, fluorescent lighting appeared as a better technology suited in the context of rising energy price and consequently emerged as a more competitive energy source compared to the incandescent bulb.

\subsection{Comparison of different lighting technologies}

According to Pode (2010), different lighting technologies could be compared based on the following characteristics: luminous efficacy - a measure of how well a lighting technology can produce visible light; installation and operation cost; colour rendering index (CRI) - an index employed for the quantification of the capacity of a light source to render colour of surfaces accurately; and lamp life. LEDs possess the highest and lowest capital and operating costs respectively among the different lighting technologies (Khorasanizadeh et al., 2015) as shown in Table 2.

Table 2: Comparison of characteristics of different lighting technologies

\begin{tabular}{|l|l|l|l|l|l|}
\hline Lamp type & $\begin{array}{l}\text { Luminous } \\
\text { efficacy } \\
\text { (lm/W) }\end{array}$ & $\begin{array}{l}\text { Lifetime of } \\
\text { lamp (h) }\end{array}$ & $\begin{array}{l}\text { Color } \\
\text { rendering } \\
\text { index }\end{array}$ & $\begin{array}{l}\text { Installation } \\
\text { cost }\end{array}$ & $\begin{array}{l}\text { Operation } \\
\text { cost }\end{array}$ \\
\hline Incandescent & $12-35$ & $2000-4000$ & 100 & Low & High \\
\hline Fluorescent & $50-100$ & $10000-16000$ & 90 & Medium & Medium \\
\hline CFL & $40-75$ & $6000-12000$ & 80 & Medium & Medium \\
\hline LED & $20-150$ & $20000-100000$ & 80 & High & Low \\
\hline
\end{tabular}

Source: Khorasanizadeh et al. (2015). 
Based on the comparison of the different lighting technologies presented in Table 2, it is anticipated that a shift in favour of the LED technology with lower energy consumption could yield significant energy savings which could translate into reduced environmental impact and climate change mitigation through reduced emissions (Khorasanizadeh et al., 2015). In this regard, a policy that will encourage the adoption of LED lighting will be beneficial to both the government and the population. In recent years, several countries have embarked on the replacement of inefficient lamps such as incandescent lamps with more efficient lighting technologies as a measure to cut down on energy cost (Azcarate et al., 2016).

\section{Methodology}

This study surveyed residential buildings in Buea, the South West Regional capital of Cameroon with the aid of a questionnaire. Microsoft Excel was used in computing the average number of each lighting technology used in the different types of surveyed dwellings and the average daily duration (hours) for lighting. An economic and environmental analysis for the substitution of incandescent lamps in the surveyed dwellings with CFLs and LEDs was conducted using Microsoft Excel spreadsheets. The economic analysis was based on the net present value (NPV), simple payback time, benefit cost ratio (BCR) and a life cycle cost (LCC) analysis. The impact of government policies pertaining to the provision of different rates of subsidy for LEDs for use in the residential sector was assessed using the return of investment for LED adoption in the first year. Sensitivity analysis was performed by varying the discount rate and the daily lighting duration.

\section{Description of survey and analysis}

\subsection{Household surveys}

A total of 100 households in the case study area were randomly sampled with the use of a questionnaire. The questionnaire was composed of four different sections. Section 1 was designed to capture socio-economic data of the surveyed household while section 2 was geared at capturing data on the characteristics of the dwelling under survey and their attitude and preferences towards different lighting technologies. The third section of the questionnaire was design to collect information on current household lighting system employed in the surveyed dwellings. This section captured information on the different types, number and power rating of bulbs used for lighting in the dwellings. The final section of the questionnaire was designed as a time of use diary to collect information on the daily duration of use of the different bulbs in the dwellings.

\subsection{Environmental analysis}

The environmental analysis for the GHG emissions associated with the use of the different lighting technologies in dwellings was conducted using the formula presented in equation 1.

$$
\text { Emission }\left(\mathrm{kgCO}_{2-e} / \mathrm{yr}\right)=\text { Activity data } x \text { emission factor }
$$

Activity data in this case represents the annual energy consumption in $\mathrm{kWh}$ for a lighting technology obtained as a product of its power rating and its duration of use in hours for a period of one year. The emission factor is the quantity of GHG emitted per unit of the activity. Put differently, it is the amount of GHG emitted per kWh of electricity consumed. The emission factor considered in this study is $860 \mathrm{~g} \mathrm{CO}_{2-\mathrm{e}} / \mathrm{kWh}$, which is the amount of emissions associated with the generation of a $\mathrm{kWh}$ of electricity in Cameroon (African Development Fund, 2009). The environmental benefits in terms of GHG emission saving 
associated with the switch from incandescent to CFL and LED lighting was obtained by simply subtracting the annual emissions associated with either CFL or LED from that of incandescent as presented in equation 2.

$$
\text { Emission savings }=E_{i}-E_{e}
$$

\section{Where;}

$\mathrm{E}_{\mathrm{i}}=$ emission associated with incandescent lighting and

$\mathrm{E}_{\mathrm{e}}=$ emission associated with efficient lighting (CFL or LED).

In order to conduct the environmental analysis, the daily duty cycle for lighting will be required. From the time of use dairy employed in the survey, the average daily required duration for artificial lighting for each dwelling was obtained by summing up the lighting duration of the seven days of the week and dividing the sum by seven. By summing up the average daily duration of all the buildings and dividing the sum by the total number of buildings, the average daily duty cycle for lighting in dwellings was determined to be six hours. The obtained average daily duty cycle for lighting alongside the average number of incandescent bulb(s) used per residential dwelling class was used as inputs in the environmental and economic analysis. Using the T1 building type as an example, the environmental analysis computation for substituting incandescent lamp with CFL is presented in Table 3, uploaded in Github (2017). The same steps were followed to determine the emission saving associated with LED for T1. The environmental analysis for the other residential building types considered in this study was performed using the same approach. A detailed result of the environmental analysis for all the building types is presented in section 6.7. Artificial lighting duration is variable over the course of the year due to varying daylight hours and for this reason, a sensitivity analysis was conducted by changing the average daily lighting duration from 6 hours to 4 and 8 hours.

\section{Table 3: Environmental analysis computation}

\begin{tabular}{|l|l|l|l|l|}
\hline $\begin{array}{c}\text { Number of } \\
\text { incandescent bulb }\end{array}$ & $\begin{array}{l}\text { Power rating of } \\
\text { incandescent bulb }\end{array}$ & Number of CFL & $\begin{array}{l}\text { Power rating of } \\
\text { CFL }\end{array}$ & $\begin{array}{l}\text { Average daily } \\
\text { duty cycle }\end{array}$ \\
\hline 1 & $60 \mathrm{~W}$ & 1 & $20 \mathrm{~W}$ & 6 hours \\
\hline $\mathrm{ADI}^{\mathrm{i}}=0.06 \mathrm{~kW}^{*} 6$ hours $* 365$ days $=131.4 \mathrm{kWh} /$ year \\
\hline $\mathrm{ADCFL}^{\mathrm{ii}}=0.02 \mathrm{~kW} * 6 \mathrm{hours} * 365$ days $=43.8 \mathrm{kWh} /$ year \\
\hline Emission from incandescent $=131.4 \mathrm{kWh} /$ year $* 0.86 \mathrm{~kg} \mathrm{CO} 2$-e $/ \mathrm{kWh}=113 \mathrm{~kg} \mathrm{CO}_{2-\mathrm{e}} /$ year \\
\hline Emission from $\mathrm{CFL}=43.8 \mathrm{kWh} /$ year $* 0.86 \mathrm{~kg} \mathrm{CO}_{2-\mathrm{e}} / \mathrm{kWh}=37.67 \mathrm{~kg} \mathrm{CO} \mathrm{CO}_{2-\mathrm{e}} /$ year \\
\hline Emission saving $=113-37.67=75.33 \mathrm{~kg} \mathrm{CO} \mathrm{CO}_{2-\mathrm{e}} /$ year \\
\hline
\end{tabular}

\subsection{Economic analysis}

Economic analysis was conducted to determine the benefits of substituting incandescent light bulbs in dwellings with CFL and LED. The 20W CFL and $60 \mathrm{~W}$ incandescent bulb were considered for the analysis since they constitute the dominant lamps used in the surveyed dwellings for the CFL and incandescent category respectively. A sensitivity analysis was conducted by varying: the daily duration of lighting from 6 hours to 4 hours and 8 hours; and the discount rate from 5 to $10 \%$. The average number of incandescent light bulbs used in the surveyed dwellings is presented in Table 1 . The T1 building type has an average of one bulb since most of this building category surveyed were a single room in an apartment rented out to mostly university students. The input data employed in the economic analysis is presented 
in Table 4. The cost of the different lighting technologies is based on commercial prices obtained from local dealers in Buea. This cost represents the capital cost of the respective bulb only, since a switch from incandescent to CFL and LED will not require a change in fittings.

\section{Table 4: Input data for the different bulb types}

\begin{tabular}{|l|l|l|l|}
\hline Bulb type & Incandescent & CFL & LED \\
\hline Power rating & 60 & 20 & 10 \\
\hline $\begin{array}{l}\text { Lifetime (h) based on } \\
\text { manufacturers' specification }\end{array}$ & 2000 & 5000 & 50000 \\
\hline Cost price (in USD) & 0.58 (CFA350) & $\begin{array}{l}0.83 \\
\text { (CFA500) }\end{array}$ & 19.88 (CFA12000) \\
\hline Average daily duty cycle (hrs) & 6 & 6 & 6 \\
\hline Lifetime (years) & 0.91 & 2.28 & 22.83 \\
\hline $\begin{array}{l}\text { Number of bulbs required for 22 } \\
\text { years }\end{array}$ & 25 & 10 & 1 \\
\hline $\begin{array}{l}\text { Lumens (as per manufacturer's } \\
\text { specification) }\end{array}$ & 720 & 1200 & 810 \\
\hline
\end{tabular}

Note: CFA the currency unit used in Cameroon. The full meaning is Communauté Financière Africaine

From Table 4, the expected lifetime of the LED bulb is $50000 \mathrm{~h}$ which corresponds to 22.83 years at a daily usage of $6 \mathrm{~h}$ while the CFL with an expectant lifetime of 5000h corresponds to 2.28 years and incandescent bulb is expected to last for $2000 \mathrm{~h}$ (0.91 year). Put differently, in 22.83 years for which a single LED could be used for lighting, incandescent lamps must be replaced 25 times and CFLs 10 times. The lumens generated by the $20 \mathrm{~W}$ CFL and the $10 \mathrm{~W}$ LED is greater than that generated by the $60 \mathrm{~W}$ incandescent bulb. It is important to reemphasise that 22.83 years on the basis of daily usage of $6 \mathrm{~h}$ for LED is not unrealistic. In Malaysia, similar results have been found (Khorasanizadeh et al., 2015).

\subsubsection{Net Present Value}

In calculating the NPV of a proposal or project, the cost and benefits needs to be quantified for the expected duration (lifetime) of the project (Commonwealth of Australia, 2006). Projects or programmes with a positive calculated NPV is indicative of the efficient use of the investor's resources and is a signal that the project could be economically viable. The NPV was computed using equation 3.

$$
N P V=\sum_{0}^{t} \frac{B_{t}-C_{t}}{(1+r)^{t}}
$$

371 Where:

$372 \quad \mathrm{~B}_{\mathrm{t}}=$ the benefit at time $\mathrm{t}$,

$373 \mathrm{C}_{\mathrm{t}}=$ the cost at time $\mathrm{t}$, and

$374 \mathrm{r}=$ is the discount rate

376 The economic benefit for the analysis represents saving through reduced electricity 377 consumption brought about by the use of energy efficient light bulbs while the cost employed 
in the analysis represents the cost of electricity supply from the grid for lighting as well as the capital (investment) cost of the efficient bulbs without need to change fittings. Using T1 as an example, the NPV for substituting incandescent lamp with CFL for year one was computed as shown in Table 5, uploaded on Github (2017). The same steps were followed for computing the NPV of the LED technology.

\section{Table 5: Computation of NPV for CFL}

\begin{tabular}{|l|l|l|l|l|}
\hline $\begin{array}{l}\text { Number of } \\
\text { incandescent bulb }\end{array}$ & $\begin{array}{l}\text { Power rating of } \\
\text { incandescent bulb }\end{array}$ & Number of CFL & $\begin{array}{l}\text { Power rating of } \\
\text { CFL }\end{array}$ & $\begin{array}{l}\text { Average daily } \\
\text { duty cycle }\end{array}$ \\
\hline 1 & $60 \mathrm{~W}$ & 1 & $20 \mathrm{~W}$ & 6 hours \\
\hline Annual electricity consumption for incandescent $=0.06 \mathrm{~kW} * 6$ hours $* 365$ days $=131.4 \mathrm{kWh} /$ year \\
\hline Annual electricity consumption for CFL $=0.02 \mathrm{~kW} * 6$ hours $* 365$ days $=43.8 \mathrm{kWh} /$ year \\
\hline \multicolumn{2}{|l|}{ Annual electricity price for incandescent $($ year 1$)=131.4 \mathrm{kWh} * \$ 0.12 / \mathrm{kWh}=\$ 15.77$} \\
\hline Annual electricity price (cost) for CFL (year 1$)=43.8 \mathrm{kWh} /$ year $* \$ 0.12 / \mathrm{kWh}=\$ 5.26$ \\
\hline Benefit of CFL in year 1 $=15.77-5.26=\$ 10.51$ \\
\hline Net cash flow $(\mathrm{NCF})=\mathrm{B}_{\mathrm{t}}-\mathrm{C}_{\mathrm{t}}=10.51-5.26=\$ 5.25$ \\
\hline NPV $=5.25 /(1+0.05)^{1}=\$ 5$ \\
\hline
\end{tabular}

The NPV for the different years was computed following the same procedure in Table 5. The NPV for the entire lifetime of the project was obtained by summing up the obtained NPV from year zero to the last year. The NPV for the different building types was obtained using the same approach.

\subsubsection{Benefit cost ratio (BCR) and simple payback period}

The benefit cost ratio was computed by dividing the total discounted benefits by the total discounted cost. Projects with benefit cost ratio greater than 1 possess greater benefits than costs and the higher the ratio, the greater the benefits relative to the costs. The simple payback period represents the time required for the profits or other benefits of an investment to equal its costs. Using T1 as an example, the BCR for substituting incandescent with CFL was computed as follows;

Total discounted benefit $=\$ 138.37$

Total discounted cost $=\$ 75.34$

$\mathrm{BCR}=\$ 138.37 / \$ 75.34=1.84$

Similarly, the BCR for the other building types were computed.

The payback period for CFL for a T1 building was achieved by determining the year in which the investment cost recuperated. The investment cost of CFL for T1 (year 0) is $\$ 0.83$ while the cash flow for year 1 is $\$ 5.26$, indicating that the real payback period is located within the first year since the $\$ 0.83$ investment is paid back. Assuming the same monthly amount of cash flow is achieved within the first year, the amount of cash flow expected at the end of each month obtained by dividing the cash flow of year one by 12 is given as $\$ 0.44$. Hence, the investment cost of $\$ 0.83$ will be paid at the end of the second month, which corresponds to a payback period of 0.17 year. The same approach was employed for obtaining the payback period of LED. In calculating the payback period of the sensitivity cases, the same procedure was followed but the yearly cash flow of the respective sensitivity case was used.. 
421

422

423

424

425

426

427

428

429

430

431

432

433

434

435

\subsubsection{Return on investment (ROI)}

Return on investment simply measures the gain or loss of an investment relative to the money invested. The higher the ROI, the higher the profits compare favourably to the costs of the investment. ROI is simply calculated by dividing the net benefits by the investment cost of the project. Using T1 as an example, the ROI for substituting incandescent lamp with LED in year one for six hours lighting duration with no government subsidy was computed as presented in Table 6, uploaded on Github (2017). Similarly, the ROI for the 4 and 8 hours duration of lighting was computed using the same approach.

Table 6: Computation of ROI for LED in year 1

\begin{tabular}{|l|l|l|}
\hline LED capital cost & $\begin{array}{l}\text { Annual electricity price for } \\
\text { incandescent lighting }\end{array}$ & $\begin{array}{l}\text { Annual electricity price for LED } \\
\text { lighting }\end{array}$ \\
\hline$\$ 19.88$ & $\$ 15.77$ & $\$ 2.63$ \\
\hline Benefits of LED $=\$ 15.77-\$ 2.63=\$ 13.14$ \\
\hline Cost for operating LED $=\$ 2.63$ \\
\hline Net benefit of LED $=\$ 13.14-\$ 2.63=\$ 10.51$ \\
\hline ROI $=(10.51 / 19.88) * 100=52.87 \%$ \\
\hline
\end{tabular}

\subsubsection{Life cycle cost analysis}

The life cycle cost analysis of a lighting technology embodies the total fixed and operating cost of the technology over its life expressed in today's money. The major cost associated with a particular lighting technology includes: the capital cost, operating and replacement cost. The LCC of the lighting technologies was computed over a duration of 22 years (rounded down from 22.83 to 22 for the worst case scenario instead of rounding up to 23), which corresponds to the lifetime of the LED bulb (used for six hours daily) considered in this study. Over the duration considered in the LCC analysis, incandescent bulbs will require to be replaced annually while CFL will need to be replaced after every two years. The present worth of the replacement cost of the technologies was computed using equation 4.

$$
C_{B}=C_{B}\left(\frac{1+i}{1+d}\right)^{n}
$$

Where; $C_{B}$ is the present worth of bulb replaced at year $n, i$ is the inflation rate while $d$ represents the discount rate adopted as $2 \%$ and $5 \%$ respectively.

Using the annual operating cost $(\mathrm{O} / \mathrm{yr})$ and the lifetime $(\mathrm{N})$, the present worth of the operating $\operatorname{cost}\left(\mathrm{C}_{\mathrm{o}}\right)$ of each technology type was computed using equation (5).

$$
C_{o}=(O / y r) \times\left(\frac{1+i}{1+d}\right)\left[\frac{1-\left(\frac{1+i}{1+d}\right)^{N}}{1-\left(\frac{1+i}{1+d}\right)}\right]
$$

436 Using the capital, the operating and replacement costs of each lighting technology, their LCC 437 was computed using equation (6).

$$
L C C=\text { Capital cost of bulb }+C_{B}+C_{o}
$$


The annualized LCC (ALCC) of each lighting technology in terms of its present value was calculated using equation (7).

$$
A L C C=L C C\left\lfloor\frac{1-\left(\frac{1+i}{1+d}\right)}{1-\left(\frac{1+i}{1+d}\right)^{N}}\right\rfloor
$$

440

\section{Analysis of results and discussion}

\subsection{Types of lighting technologies used and their power rating}

The results of the survey revealed that three different types of light bulbs are used in dwellings. These include: incandescent, CFL and fluorescent tubes. LED was not used in any of the surveyed dwellings. Majority $(15.2 \%)$ of the surveyed households used CFL only for lighting while $12 \%$ and $10.9 \%$ used only incandescent and fluorescent tube respectively for lighting and this is supported by the claim of Richardson et al. (2009) which holds that the number of installed lighting units, the lighting technologies used and their power ratings varies from dwelling to dwelling with the variation accounted by human choice. Over $60 \%$ of surveyed dwellings use a combination of two or all three of the technologies for lighting as indicated in Figure 1 and this corroborates a study by Enongene et al. (2016) who found that residential dwellings in Cameroon use a mixture of different lighting technologies for artificial lighting. Of the incandescent lamps used in the surveyed dwellings, the $60 \mathrm{~W}$ incandescent lamp dominates as it is the most widely used for this category of lighting technology as shown in Table 7. Residential lighting with CFLs is dominated by the $20 \mathrm{~W}$ lamp since it was used in 33 of the surveyed dwellings as presented in Table 7. Lighting of dwellings using fluorescent tube is through the use of two main bulbs: $40 \mathrm{~W}$ and $60 \mathrm{~W}$. Fluorescent tube lighting is dominated by the $40 \mathrm{~W}$ category which was found to be used in 43 dwellings while the $60 \mathrm{~W}$ fluorescent tube was used in 21 dwellings.

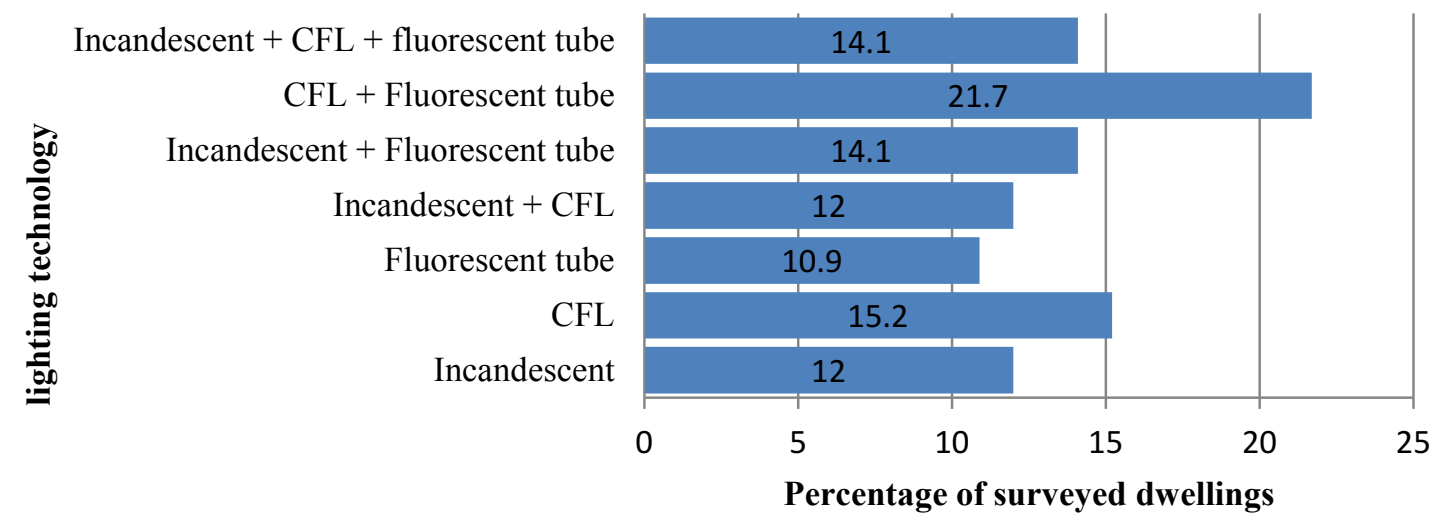

460

Figure 1: Current lighting technologies used in dwellings

Table 7: Power rating of incandescent bulbs and CFLs used in dwellings

\begin{tabular}{|l|c|c|c|c|}
\hline Bulb type & \multicolumn{4}{|l|}{ Power rating and number of buildings where used } \\
\hline Inc & $40 \mathrm{~W}(6)$ & $60 \mathrm{~W} \mathrm{(36)}$ & $75 \mathrm{~W}(7)$ & $100 \mathrm{~W}(8)$ \\
\hline
\end{tabular}




(1) (2) (33)

(3)

(1)

(2)

(1)

(10)

(3)

(3)

(6)

463

464

465

466

467

468

469

470

471

472

473

474

475

476

477

478

479

480

481

482

483

484

485

486

487

488

489

490

491

492

493

494

495

496

497

498

499

500

Where Inc: incandescent and the numbers in parenthesis represents the number of surveyed building(s) in which a bulb of a particular power rating is used.

\subsection{Potential factors influencing the adoption of efficient lighting (LED)}

From the surveys, household income, level of education of household head and unit type emerged as possible factors that have potential of influencing the adoption of LED in residential buildings. It was found out that the higher the income of a household head, the more financially viable and likelihood of the household to invest in LED lighting. The same trend is expected for the level of education of household head. The higher the educational level of a household head, the greater the likelihood of LED adoption since such individuals are likely to understand the benefits in terms of cost reduction associated with the transition towards efficient lighting. This agrees with studies by Mills and Schleich (2012) who reported that income and education levels are determinants of energy-efficient technology adoption with higher levels of income and education associated with energy-efficient technology adoption. Preference for LED lighting increased among households following a disclosure of information on energy savings and cost reduction associated with LED lighting. In a similar study conducted by Zhou and Bukenya (2016), the authors reported that energy savings information of a technology significantly impacts the willingness of the consumer to pay for that technology. Pertaining to unit type, the survey revealed that single-family detached dwellings are more likely to adopt LED lighting compared to apartment dwellings. This is not unexpected due to the sharing of a common electricity meter which is common among apartment dwellings in the study area unlike single-family detached houses with an own electricity meter. Hence, apartment dwellings with a shared electricity meter are not motivated to invest in LED lighting since the monthly electricity bills from the power company is shared among households who tend to be dissatisfied with the amount they are charged to pay. Under such a scenario, dwellings will prefer to use incandescent lamps with low capital but high operating cost for lighting. The sharing of electricity meters therefore stands out as a disincentive for the adoption of LED lighting in dwellings since energy savings which translate into cost reduction is an incentive for household occupants to invest in energy efficient technologies (Stephan \& Stephan, 2016).

\subsection{Energy consumption of lighting technologies}

The annual energy consumption for each lamp type based on a daily lighting duration of 6 hours for the different building classes is presented in Table 8. The energy consumption of each lamp type increases from T1 through to T5 due to an increase in the number of bulbs and decreases to T6. The energy consumption decreases from T5 to T6 because the latter uses less number of incandescent bulbs for lighting than the former. The results of the sensitivity analysis revealed an increase in the energy consumption for all the lighting technologies with an increase in the lighting duration as shown in Figure 2.

Table 8: Quantity of energy consumed (kWh/year) by each lighting technology

\begin{tabular}{|l|c|c|c|c|c|c|}
\hline Building class & T1 & T2 & T3 & T4 & T5 & T6 \\
\hline Number of bulbs required & 1 & 3 & 4 & 5 & 6 & 4 \\
\hline Incandescent (60W) & 131.4 & 394.2 & 525.6 & 657 & 788.4 & 525.6 \\
\hline CFL (20W) & 43.8 & 131.4 & 175.2 & 219 & 262.8 & 175.2 \\
\hline LED (10W) & 21.9 & 65.7 & 87.6 & 109.5 & 131.4 & 87.6 \\
\hline
\end{tabular}




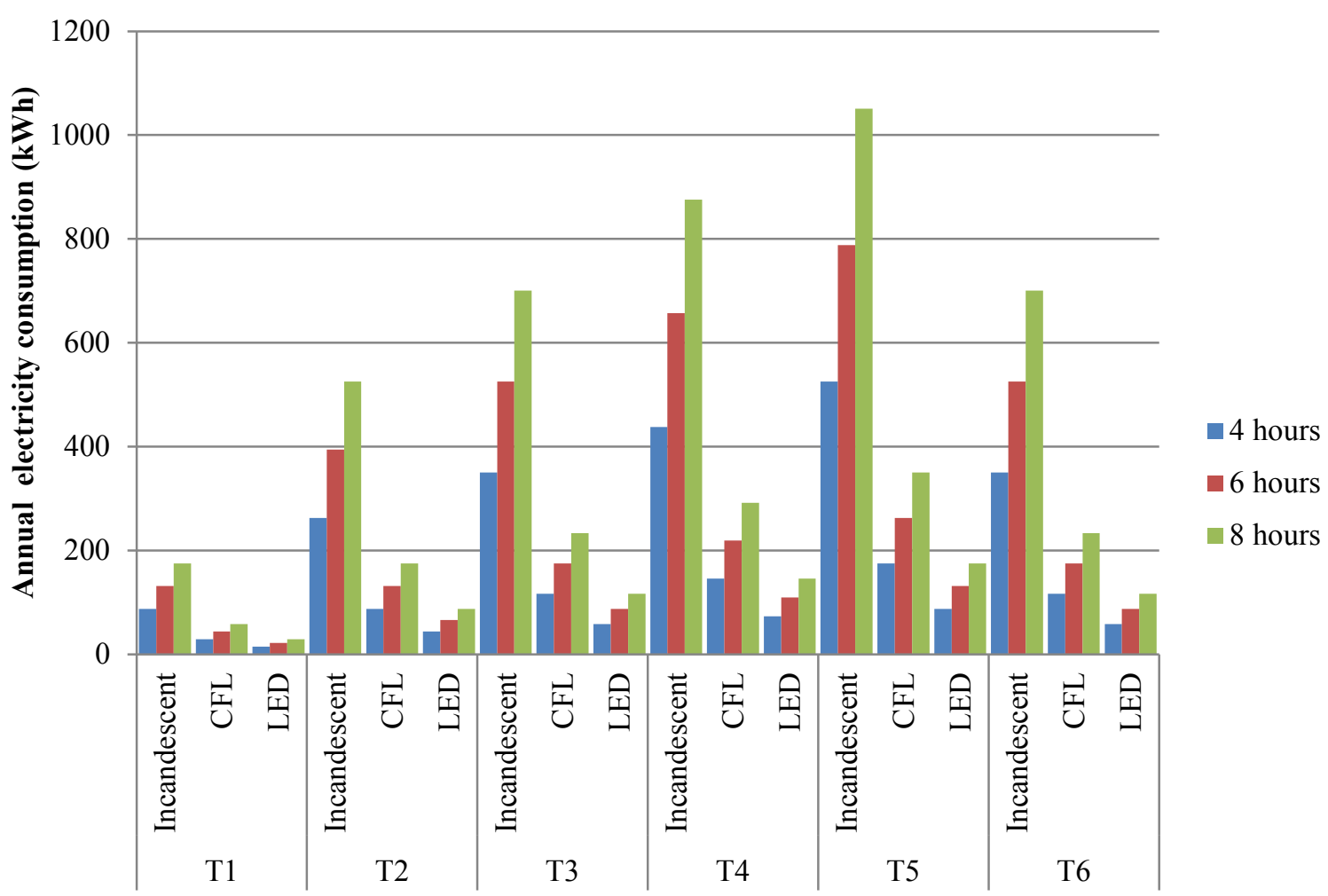

502

Building class and lighting technologies

\section{Figure 2: Variation of energy consumption with number of lighting hours}

504

505

506

507

508

509

510

511

512

513

514

515

516

517

518

519

520

\subsection{Annual electricity cost for lighting using different lamps}

The annual electricity cost for lighting of the different lighting technologies and for different dwelling categories based on the current electricity tariff in Cameroon (US\$0.12/kWh) is presented in Table 9. The electricity price followed the same trend like the energy consumption, increasing from $\mathrm{T} 1$ through to $\mathrm{T} 5$ and decreasing to $\mathrm{T} 6$. A switch from incandescent lighting to CFL reduces the annual electricity bill by $66.8 \%$ while a switch from incandescent to LED lighting reduces annual electricity bill by $83 \%$ as indicated in Table 9 . This reduction in power consumption and consequently electricity bills concords with the findings of Aman et al. (2013) which holds that the use of LED is not only beneficial for utility, but for consumers as well. The reduction in energy consumption brought about by the use of the LED technology reduces the pressure on the utility grid on one hand while resulting to electricity cost reduction for consumers on the other hand. The implementation of energy efficiency measures in buildings have a potential role to play in reducing the amount of electricity to be generated (Batih \& Sorapipatana, 2016) and this eliminates the need for the construction of new power plants. The transition towards LED yields the greatest energy cost reduction since the wattage of the LED bulb is lower than that of CFL and incandescent.

Table 9: Annual electricity cost (USD) for lighting of different lamps

\begin{tabular}{|c|c|c|c|c|c|c|c|}
\hline Building class & T1 & T2 & T3 & T4 & T5 & T6 & Reduction (\%) \\
\hline Incandescent & 15.77 & 47.30 & 63.07 & 78.84 & 94.608 & 63.072 & 0 \\
\hline
\end{tabular}


521

\begin{tabular}{|c|c|c|c|c|c|c|c|}
\hline CFL & 5.23 & 15.77 & 21.02 & 26.28 & 31.54 & 21.02 & 66.8 \\
\hline LED & 2.63 & 7.88 & 10.51 & 13.14 & 15.77 & 10.51 & 83 \\
\hline
\end{tabular}

\subsection{Investment profitability}

The results of the economic analysis for the substitution of incandescent bulbs with CFLs and LEDs in the different residential buildings using the average daily artificial lighting duration of six hours is presented in Table 10.

Table 10: Results of economic analysis for substitution incandescent lamps with efficient lighting based on 6 hours lighting duration.

\begin{tabular}{|c|c|c|c|c|c|c|c|}
\hline \multicolumn{2}{|c|}{ Building class } & T1 & T2 & T3 & T4 & T5 & T6 \\
\hline \multirow{2}{*}{ NPV } & CFL & $\$ 60.02$ & $\$ 180.07$ & $\$ 240.10$ & $\$ 300.12$ & $\$ 360.14$ & $\$ 240.10$ \\
\cline { 2 - 8 } & LED & $\$ 112.85$ & $\$ 338.54$ & $\$ 451.39$ & $\$ 564.24$ & $\$ 677.08$ & $\$ 451.39$ \\
\hline \multirow{3}{*}{ BCR } & CFL & 1.84 & 1.84 & 1.84 & 1.84 & 1.84 & 1.84 \\
\cline { 2 - 8 } & LED & 3.18 & 3.18 & 3.18 & 3.18 & 3.18 & 3.18 \\
\hline \multirow{2}{*}{ PBP } & CFL & 0.17 year & 0.17 year & 0.17 year & 0.17 year & 0.17 year & 0.17 year \\
\cline { 2 - 8 } & LED & 1.92 & 1.92 & 1.92 & 1.92 & 1.92 & 1.92 \\
& & years & years & years & years & years & years \\
\hline
\end{tabular}

The economic benefit for the analysis represents saving through reduced electricity consumption brought about by the use of energy efficient light bulbs. The cost employed in the analysis represents the cost of electricity supply from the power company for lighting as well as the capital cost of the efficient bulbs without need to change fittings. The NPV for CFL ranges from $\$ 60.02$ to $\$ 360.14$ while that for LED ranges from $\$ 112.85$ to $\$ 677.08$. The NPV of LED is higher than that of CFL per building class, implying that transition to LED appears to be a more profitable option. The simple payback period for CFL and LED were obtained as 0.17 year and 1.92 years respectively. CFL has a lower payback period compared to LED due to its lower capital cost (Khorasanizadeh et al., 2015). The benefit cost ratio (BCR) for CFL and LED were obtained as 1.84 and 3.18 respectively. The higher BCR of LED implies that it yields greater benefits irrespective of its higher capital cost. According to Chueco et al. (2015), these benefits of LED are associated with its low energy consumption and long useful lifetime. A sample worksheet used for the economic analysis is presented in Appendix I, uploaded on Github (2017).

The results of the sensitivity analysis performed on the average daily artificial lighting duration are presented on Table 11 and Table 12.

Table 11: Results of economic analysis based on daily lighting duration of 4 hours

\begin{tabular}{|c|c|c|c|c|c|c|c|}
\hline \multicolumn{2}{|c|}{ Building class } & T1 & T2 & T3 & T4 & T5 & T6 \\
\hline \multirow{2}{*}{ NPV } & CFL & $\$ 47$ & $\$ 141.01$ & $\$ 188.01$ & $\$ 235.02$ & $\$ 282.02$ & $\$ 188.01$ \\
\cline { 2 - 8 } & LED & $\$ 89.14$ & $\$ 267.43$ & $\$ 356.57$ & $\$ 445.71$ & $\$ 370.37$ & $\$ 356.57$ \\
\hline \multirow{2}{*}{ BCR } & CFL & 1.77 & 1.77 & 1.77 & 1.77 & 1.77 & 1.77 \\
\cline { 2 - 8 } & LED & 2.58 & 2.58 & 2.58 & 2.58 & 2.58 & 2.58 \\
\hline \multirow{2}{*}{ PBP } & CFL & 0.25 year & 0.25 year & 0.25 year & 0.25 year & 0.25 year & 0.25 year \\
\cline { 2 - 8 } & LED & 2.83 & 2.83 & 2.83 & 2.83 & 2.83 & 2.83 \\
\hline
\end{tabular}




\begin{tabular}{|l|l|l|l|l|l|l|l|}
\hline & & years & years & years & years & years & years \\
\hline
\end{tabular}

547 Table 12: Results of economic analysis based on daily lighting duration of 8 hours

\begin{tabular}{|c|c|c|c|c|c|c|c|}
\hline \multicolumn{2}{|c|}{ Building class } & T1 & T2 & T3 & T4 & T5 & T6 \\
\hline \multirow{2}{*}{ NPV } & CFL & $\$ 70.28$ & $\$ 210.83$ & $\$ 281.11$ & $\$ 351.38$ & $\$ 421.66$ & $\$ 281.11$ \\
\cline { 2 - 8 } & LED & $\$ 131.56$ & $\$ 394.68$ & $\$ 526.24$ & $\$ 657.80$ & $\$ 789.36$ & $\$ 526.24$ \\
\hline \multirow{2}{*}{ BCR } & CFL & 1.88 & 1.88 & 1.88 & 1.88 & 1.88 & 1.88 \\
\cline { 2 - 8 } & LED & 3.33 & 3.33 & 3.33 & 3.33 & 3.33 & 3.33 \\
\hline \multirow{2}{*}{ PBP } & CFL & 0.13 year & 0.13 year & 0.13 year & 0.13 year & 0.13 year & 0.13 year \\
\cline { 2 - 8 } & LED & 1.5 years & 1.5 years & 1.5 years & 1.5 years & 1.5 years & 1.5 years \\
\hline
\end{tabular}

549 The NPV of CFL and LED increases with an increase in the duration of artificial lighting as 550 shown in Figure 3.

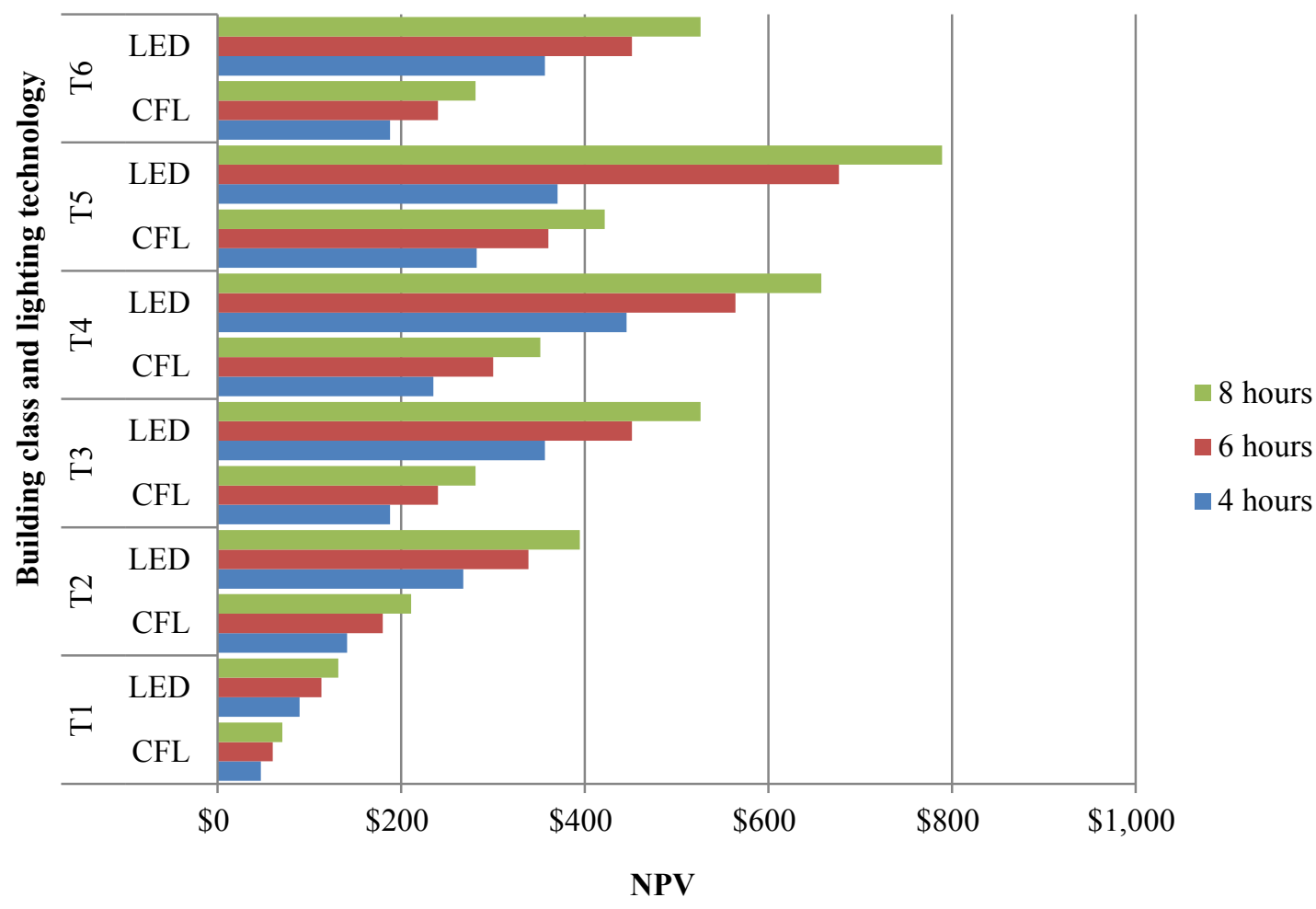

551

552 Figure 3: Variation of NPV with daily lighting duration

553 The BCR for both CFL and LED increases with increase in the lighting duration (Table 13)

554 while the PBP for both lighting technologies decreases with an increase in the daily duration 555 of artificial lighting as shown in Table 13. This implies that, transition from incandescent to 556 more efficient lighting technologies is more beneficial for longer lighting durations. Hence, it 557 would be more beneficial for dwellings to replace an incandescent lamp used for longer 558 durations such as security light, with LED. 
Table 13: Benefit cost ratio and payback period of CFL and LED for different lighting durations

\begin{tabular}{|l|c|c|c|c|c|c|}
\hline Lighting technology & \multicolumn{3}{|c|}{ Benefit cost ratio } & \multicolumn{3}{c|}{ Payback period (years) } \\
\hline & 4 hours & 6 hours & 8 hours & 4 hours & 6 hours & 8 hours \\
\hline CFL & 1.77 & 1.84 & 1.88 & 0.25 & 0.17 & 0.13 \\
\hline LED & 2.59 & 3.18 & 3.33 & 2.83 & 1.92 & 1.5 \\
\hline
\end{tabular}

561

The result of the sensitivity analysis using $10 \%$ discount rate is presented in Table 14 . The NPV for both CFL and LED witnessed a decrease with an increase in the discount rate from 5 to $10 \%$ (See Figure 4). The BCR of CFL decreased from 1.84 at 5\% discount rate to 1.83 at $10 \%$ discount rate while that of LED decreased from 3.18 at $5 \%$ discount rate to 2.68 at $10 \%$ discount rate. The PBP witnessed no change with an increase in the discount rate.

Table 14: Result of sensitivity analysis using $10 \%$ discount rate

\begin{tabular}{|c|c|c|c|c|c|c|c|}
\hline \multicolumn{2}{|c|}{ Building class } & T1 & T2 & T3 & T4 & T5 & T6 \\
\hline \multirow{2}{*}{ NPV } & CFL & $\$ 38.01$ & $\$ 114.02$ & $\$ 152.02$ & $\$ 190.03$ & $\$ 228.03$ & $\$ 152.02$ \\
\cline { 2 - 8 } & LED & $\$ 65.75$ & $\$ 197.25$ & $\$ 263.01$ & $\$ 328.76$ & $\$ 394.51$ & $\$ 263.01$ \\
\hline \multirow{3}{*}{ BCR } & CFL & 1.83 & 1.83 & 1.83 & 1.83 & 1.83 & 1.83 \\
\cline { 2 - 8 } & LED & 2.68 & 2.68 & 2.68 & 2.68 & 2.68 & 2.68 \\
\hline \multirow{2}{*}{ PBP } & CFL & 0.17 year & 0.17 year & 0.17 year & 0.17 year & 0.17 year & 0.17 year \\
\cline { 2 - 8 } & LED & 1.92 & 1.92 & 1.92 & 1.92 & 1.92 & 1.92 \\
& & years & years & years & years & years & years \\
\hline
\end{tabular}

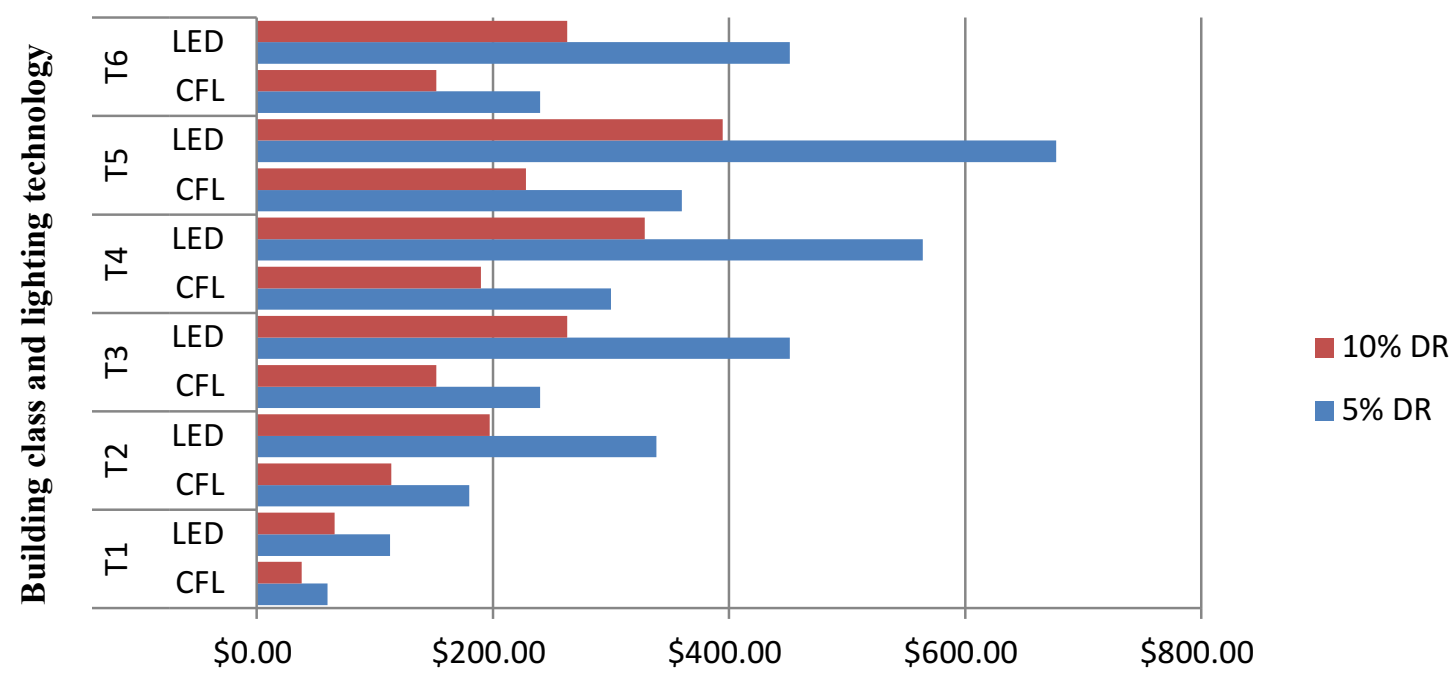

571 The result of the LCC analysis is presented in Figure 5. 


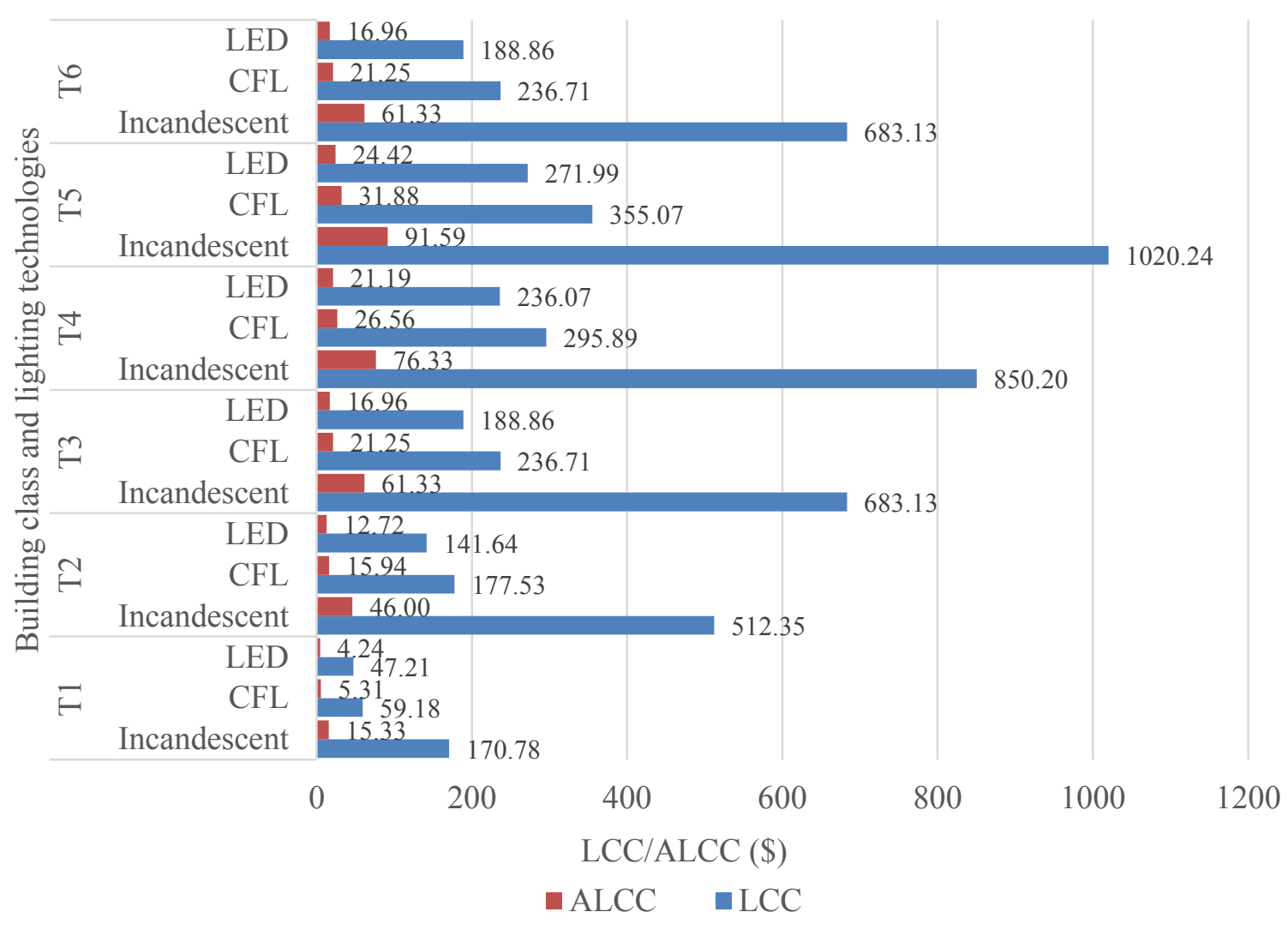

574 Figure 5: Results of LCC analysis of different lighting technologies employed in 575 residential dwellings.

576 The LCC and the ALCC of the LED technology is the least for all the building classes 577 seconded by CFL while incandescent emerged as the lighting technology with the highest 578 LCC and ALCC. Albeit the high capital cost of the LED technology, it emerges as the most 579 economically viable technology for artificial lighting compared to CFL and incandescent as a 580 result of its low operating cost and zero replacement cost. The incandescent technology with 581 the lowest capital cost proves the most uneconomically viable option due to its high operating 582 and replacement cost. The reduction of energy consumption brought about by an 583 improvement in energy efficiency translates into cost savings (al Irsyad \& Nepal, 2016).

6.6 Possible effect of subsidy by the Cameroon government on the return of investment of LED

Albeit the long term economic benefits associated with the use of the LED technology in residential dwellings, the high capital cost of the technology could stand as a disincentive for its adoption. This corroborates the study conducted by Zografakis et al. (2012) who found out that office buildings where the cost of replacing all incandescent lamps by energy efficient ones was high were less likely to adopt energy efficient lamps. The subsidization of energy efficient lighting technologies is crucial for their uptake in such buildings. The possible impact of the government of Cameroon on LED adoption through the provision of subsidy is examined in this section. The potential outcome of different rates of government subsidy (on LED purchase cost) on the return of investment of LED in the first year of adoption is presented in Figure 6. The return on investment increases with an increase in the subsidy rate by the government for all three daily artificial lighting durations. The return on investment as 
well increases with an increase in the lighting duration. A return on investment that is greater than one (1) depicts that the investment or project is profitable and worthwhile. For the six and eight hours lighting duration scenarios, with a government subsidy of $10 \%$ and $5 \%$ respectively on the LED capital cost within the first year, consumers would experience a return on their investment since the ROI is equal to one for the six hours duration and greater than one for the 8 hours duration. For the four hours lighting scenario, consumers would be able to experience a return within the first year if the government of Cameroon could subsidize the capital cost of LED by $30 \%$. The subsidy to be paid by the government would translate into reduced electricity consumption in the residential sector and GHG emission savings (Khorasanizadeh et al., 2015). This is as well supported by Zografakis et al. (2012) who concluded that the provision of subsidy for energy efficient lighting technologies yields benefits to the environment and the society in general.

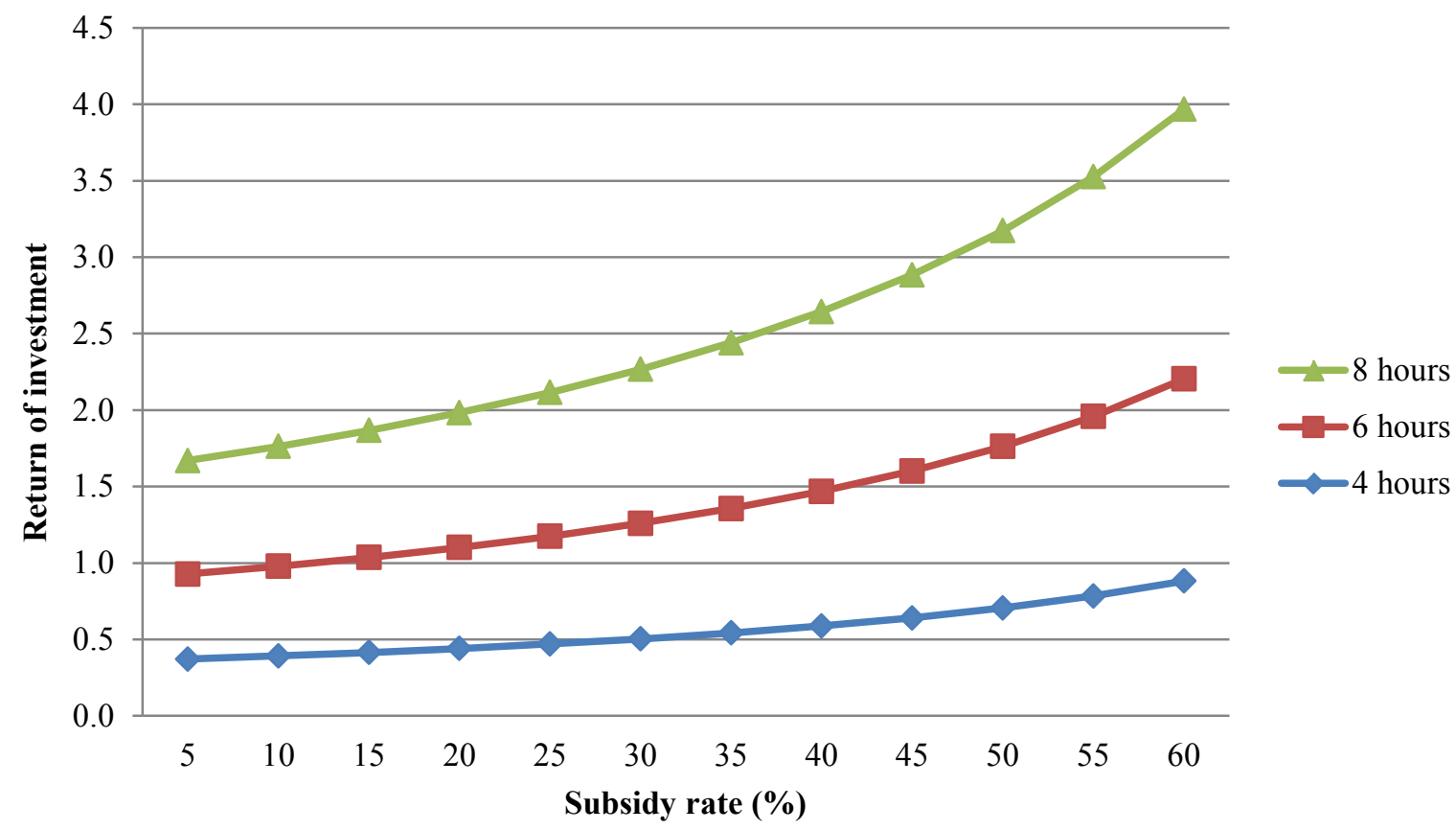

609

610 Figure 6: Return of investment for different subsidy rate and lighting durations by substituting incandescent lamps with LEDs in the first year

\section{6.7 Environmental Potential of efficient lighting adoption}

613 The environmental analysis was conducted for the operational phase of the technologies. The 614 results of the environmental benefits in terms of greenhouse gas emission savings of replacing incandescent lamps with CFLs and LEDs in residential buildings for an average daily duration of use of 6 hours is presented in Table 15. The lower carbon emissions associated with the LED technology compared to the traditional lighting mode results in an increasing interest of the role of LED in addressing environmental impact of lighting systems (Khorasanizadeh et al., 2016).

621 lamp by CFL and LED

\begin{tabular}{|l|l|l|l|l|l|l|}
\hline Building class & T1 & T2 & T3 & T4 & T5 & T6 \\
\hline Emissions from incandescent & 113 & 339.01 & 452.02 & 565.02 & 678.02 & 452.02 \\
\hline
\end{tabular}




\begin{tabular}{|l|l|l|l|l|l|l|}
\hline Emissions from CFL & 37.67 & 113 & 150.67 & 188.34 & 226.01 & 150.67 \\
\hline Emissions from LED & 18.83 & 56.50 & 75.34 & 94.17 & 113 & 75.34 \\
\hline CFL emission saving & 75.34 & 226.01 & 301.34 & 376.68 & 452.02 & 301.34 \\
\hline LED Emission saving & 94.17 & 282.51 & 376.68 & 470.85 & 565.02 & 376.68 \\
\hline CFL \% emission reduction & 66.6 & 66.6 & 66.6 & 66.6 & 66.6 & 66.6 \\
\hline LED \% emission reduction & 83.3 & 83.3 & 83.3 & 83.3 & 83.3 & 83.3 \\
\hline
\end{tabular}

622

The GHG emission savings increases from $\mathrm{T} 1$ to $\mathrm{T} 5$ and decreases to $\mathrm{T} 6$. The GHG emission savings was computed using the emission factor of $860 \mathrm{gCO}_{2-\mathrm{e}} / \mathrm{kWh}$, which corresponds to the emission associated with the generation of a $\mathrm{kWh}$ of electricity in Cameroon. The environmental benefits associated with LED is greater than that of CFL and this is in agreement with the study of Principi and Fioretti (2014) who assessed the life cycle environmental burden of CFL and LED and concluded that LED has a significant impact on reducing carbon footprints as a result of its higher energy efficiency during its operational phase. The lower carbon emissions associated with the LED technology compared to the traditional lighting mode results in an increasing interest of the role of LED in addressing environmental impact of lighting systems (Khorasanizadeh et al., 2016).

The environmental potentials of both lighting technologies increased with an increase in the daily duration of artificial lighting in dwellings. The result of the sensitivity analysis on the environmental benefits of replacing incandescent lamps with CFLs and LEDs is presented in Figure 7.

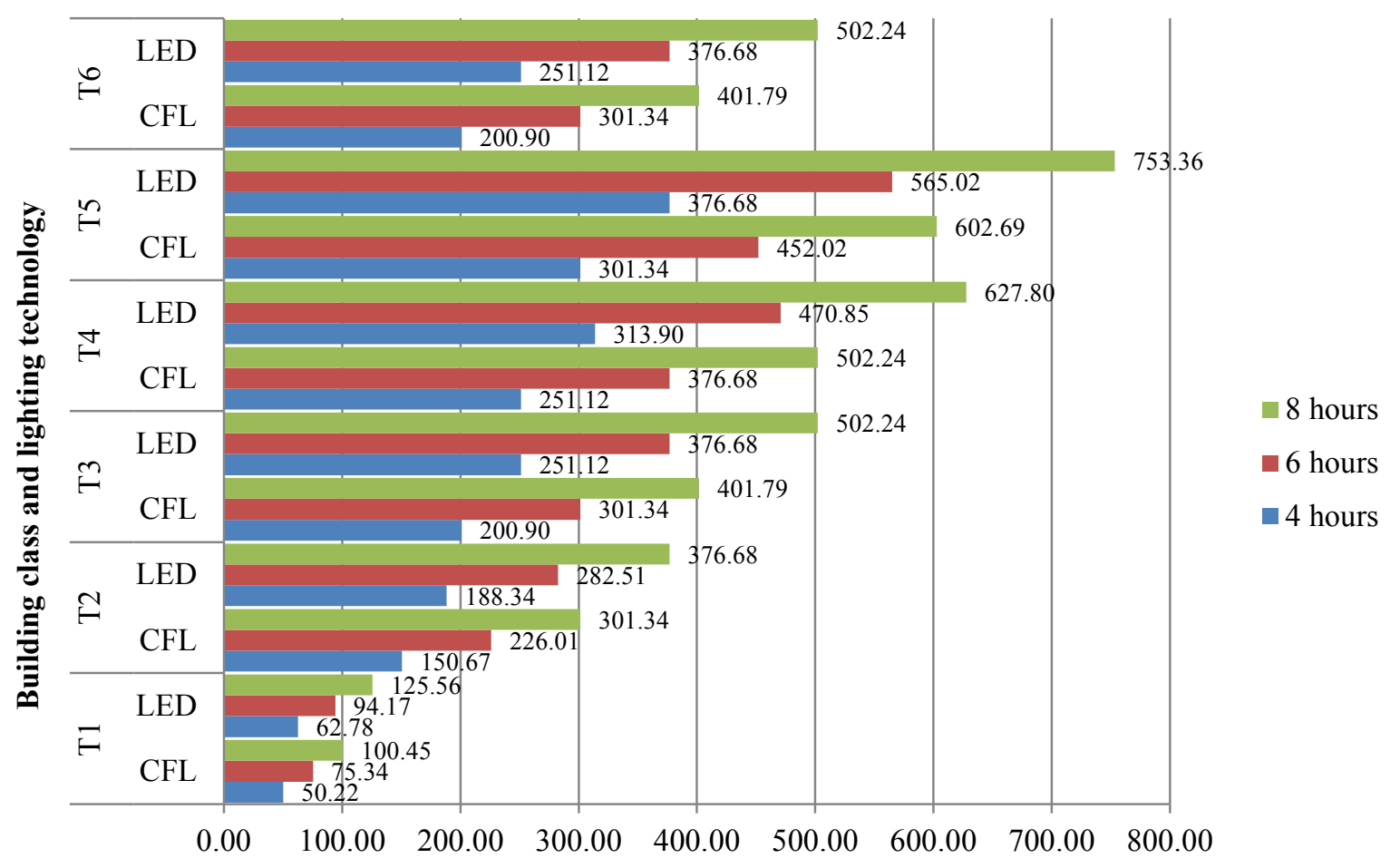

GHG emission savings ( $\mathrm{kg}$ of $\mathrm{CO}_{2}$-e) 
641 With an increase in the power crisis in developing countries coupled with global concerns 642 over climate change, there is a clear rationale for the reduction in energy consumption. The use of energy efficient appliances is one major way of reducing energy consumption and mitigating climate change. This study focussed on assessing the economic and environmental benefits associated with a transition from incandescent lighting to CFL and LED in different residential building types (T1 to T6) in Buea, Cameroon. The study encompasses a survey of residential buildings, an economic and environmental analysis. Artificial lighting in residential buildings in Cameroon is achieved through the use of incandescent lamps, compact fluorescent lamps and fluorescent tube dominated by $60 \mathrm{~W}, 20 \mathrm{~W}$ and $40 \mathrm{~W}$ respectively.

Results of the economic and environmental analysis revealed that a switch from incandescent lighting to CFL and LED in all the different classes of residential building culminates in economic and environmental benefits through reduction in energy bills and greenhouse gas emission savings respectively with greater benefits achieved for LED. The results conclude that albeit transition towards efficient lighting in the residential sector of Cameroon has potential to culminate in the reduction of greenhouse gas emissions and energy consumption, there is a likelihood of resistance pertaining to the adoption of LED lighting among apartment dwellings as a result of the sharing of a common electricity metre. The sharing of a common electricity meter in apartment dwellings is therefore a potential factor that will affect the transition towards LED lighting in the residential sector of Cameroon. Hence, proposed strategies adopted by national governments geared towards the adoption of energy efficient technologies at the country level should take into account national circumstances since strategies used in one country may not easily be replicated in other countries.

While a country wide national campaign on the benefits of LED and the formulation and implementation of favourable government policies that would promote the adoption of the LED technology has a role to play in the transition towards efficient lighting in Cameroon, further studies on the energy saving potentials of LED lighting that takes into account the percentage of apartment dwellings and single family detached dwellings in Cameroon should be conducted as well as the identification of possible mechanisms whose implementation would provide incentives for apartment dwellings to adopt LED lighting. Also, there is need for further research in this area to survey few hundred households in Cameroon based on which a meaningful statistical analysis could be conducted to identify variables that would influence the adoption of LED lighting.

\section{Acknowledgement}

The authors would like to thank the New Zealand Ministry of Foreign Affairs and Trade (MFAT) for funding this study. 


\section{References}

Abanda, F.H. (2012). Renewable energy sources in Cameroon: potentials, benefits and enabling environment. Renewable and Sustainable Energy Reviews, 16 (7), 45574562

Abanda F.H. and Cabeza L.F. (2015) Investigating occupants' behaviour using emerging Building Information Modelling. In the proceedings of the ICSC15 - The CSCE International Construction Specialty Conference, Vancouver, June 7 - 10, 2015.

African Development Fund (2009). Project to strengthen and extend the electricity transmission and distribution networks in the Republic of Cameroon. Appraisal report. Available at: $<$ http://www.afdb.org/fileadmin/uploads/afdb/Documents/Project-and-Operations/\%20Cameroon\%20-\%20AR\%20Electricity\%20Project\%20-\%5B1\%5D.pdf>

AES-SONEL. Annual report 2011. Available at: http://investor.aes.com/phoenix.zhtml?c=76149\&p=irol-reportsannual .

AlAjmi, A., Abou-Ziyan, H., \& Ghoneim, A. (2016). Achieving annual and monthly net-zero energy of existing building in hot climate. Applied Energy, 165, 511-521.

al Irsyad, M. I., \& Nepal, R. (2016). A survey based approach to estimating the benefits of energy efficiency improvements in street lighting systems in Indonesia. Renewable and Sustainable Energy Reviews, 58, 1569-1577. doi: http://dx.doi.org/10.1016/j.rser.2015.12.294

Aman, M. M., Jasmon, G. B., Mokhlis, H., \& Bakar, A. H. A. (2013). Analysis of the performance of domestic lighting lamps. Energy Policy, 52, 482-500.

Azcarate, I., Gutierrez, J. J., Lazkano, A., Saiz, P., Redondo, K., \& Leturiondo, L. A. (2016). Towards limiting the sensitivity of energy-efficient lighting to voltage fluctuations. Renewable and Sustainable Energy Reviews, 59, 1384-1395. doi: http://dx.doi.org/10.1016/j.rser.2016.01.022

Ayompe, L. M. and Duffy, A. (2014). An assessment of the energy generation potential of photovoltaic systems in Cameroon using satellite-derived solar radiation datasets. Sustainable Energy Technologies and Assessments 7, 257-264.

Batih, H., \& Sorapipatana, C. (2016). Characteristics of urban households' electrical energy consumption in Indonesia and its saving potentials. Renewable and Sustainable Energy Reviews, 57, 1160-1173. doi: http://dx.doi.org/10.1016/j.rser.2015.12.132

Chueco, F., López, F., \& Bobadilla, M. (2015). Technical and economic evaluation of fluorescent and LED luminaires in underground mining. A case study: New mine level of E1 Teniente. Energy and Buildings, 93, 16-22.

Commonwealth of Australia (2006). Introduction to Cost-Benefit Analysis and alternative evaluatiob methodologies, Commonwealth of Australia. Retrieved from: http://www.finance.gov.au/sites/default/files/Intro_to_CB_analysis.pdf

de la Rue du Can, S., Price, L., \& Zwickel, T. (2015). Understanding the full climate change impact of energy consumption and mitigation at the end-use level: A proposed 
methodology for allocating indirect carbon dioxide emissions. Applied Energy, 159, 548-559.

Enongene, K. E., Murray, P., Holland, J., Abanda, F. H. \& Manjia, M. B. (2016). Trends in the use of domestic energy appliances in Cameroon. Proceedings of the Sustainable Built Environment 2016 Conference, Dubai, United Arab Emirates.

European Union Energy Initiative Partnership Dialogue Facility. (2014). National Energy Efficiency Policy, Strategy and Action Plan in the electricity sector in Cameroon Retrieved from: http://euei-pdf.org/country-studies/development-of-a-nationalenergy-efficiency-policy-and-plan

Forster, P., Ramaswamy, V., Artaxo, P., Berntsen T., Betts, R., Fahey, D.W., Haywood, J., Lean, J., Lowe, D.C., Myhre, G., Nganga J., Prinn, R., Raga, G., Schulz, M., \& Van Dorland, R. (2007). Changes in Atmospheric Constituents and in Radiative Forcing. In Solomon, S., D. Qin, M. Manning, Z. Chen, M. Marquis, K.B. Averyt, M. Tignor and H.L. Miller (Eds.), Climate Change 2007: The Physical Science Basis (pp. 130234). Cambridge and New York: Cambridge University Press.

Figueroa, A. R. (2016). Efficient lighting uptake among the urban poor: evidence from a Kenyan informal settlement. Environment and Urbanization, 0956247816647871.

Fotsing, F. I. M., Njomo, D. \& Tchinda, Rene (2014). Analysis of Demand and Supply of Electrical Energy in Cameroon: Influence of Meteorological Parameters on the Monthly Power Peak of South and North Interconnected Electricity Networks. International Journal of Energy and Power Engineering. 3(4), 168-185. doi: 10.11648/j.ijepe.20140304.12

Girod, B., van Vuuren, D. P., \& Hertwich, E. G. (2014). Climate policy through changing consumption choices: Options and obstacles for reducing greenhouse gas emissions. Global Environmental Change, 25(0), 5-15.

Github (2017) Energy-efficiency-savings-in-Cameroon. Retrived from: https://github.com/fonbeyinhenry/Energy-efficiency-savings-in-Cameroon

Global Buildings Performance Network. (2015). A global spotlight on energy efficiency in buildings. Retrieved from: http://www.gbpn.org/newsroom/news-global-spotlightenergy-efficiencybuildings?utm_source $=$ newsletter\&utm_medium $=$ email\&utm_campaign $=$ Newsletter $\% 2013 \% 20-\% \overline{2}$ 0COP21,\%20a\%20global\%20deal

Government of Cameroon (2010). GESP: Growth and Employment Strategy Paper ; reference framework for government action over the period 2010 - 2020 ; August 2009. International. Monetary Fund, Washington, DC

Hernández, D. \& Phillips, D. (2015). Benefit or burden? Perceptions of energy efficiency efforts among low-income housing residents in New York City. Energy Research and Social Science, 8, 52-59.

Hicks, A. L., Theis, T. L. \& Zellner, M. L. (2015). Emergent Effects of Residential Lighting Choices: Prospects for Energy Savings. Journal of Industrial Ecology 19(2), 285-295. 
Khorasanizadeh, H., Parkkinen, J., Parthiban, R., \& Moore, J. D. (2015). Energy and economic benefits of LED adoption in Malaysia. Renewable and Sustainable Energy Reviews, 49, 629-637.

Khorasanizadeh, H., Honarpour, A., Park, M. S.-A., Parkkinen, J., \& Parthiban, R. (2016). Adoption factors of cleaner production technology in a developing country: energy efficient lighting in Malaysia. Journal of Cleaner Production, 131, 97-106. doi: http://dx.doi.org/10.1016/j.jclepro.2016.05.070

Li, C., Hong, T., \& Yan, D. (2014). An insight into actual energy use and its drivers in highperformance buildings. Applied Energy, 131, 394-410.

Lucon O., D., Ürge-Vorsatz, A., Zain Ahmed, H., Akbari, P., Bertoldi, L.F., Cabeza, N., Eyre, A., Gadgil, L.D.D., Harvey, Y., Jiang, E., Liphoto, S., Mirasgedis, S., Murakami, J., Parikh, C., Pyke, and Vilariño, M.V. (2014). Buildings. In: Climate Change 2014: Mitigation of Climate Change. Contribution of Working Group III to the Fifth Assessment Report of the Intergovernmental Panel on Climate Change [Edenhofer, O., R. Pichs-Madruga, Y. Sokona, E. Farahani, S. Kadner, K. Seyboth, A. Adler, I. Baum, S. Brunner, P. Eickemeier, B. Kriemann, J. Savolainen, S. Schlömer, C. von Stechow, T. Zwickel and J.C. Minx (eds.)]. Cambridge University Press, Cambridge, United Kingdom and New York, NY, USA.

Luo, M. R. (2011). The quality of light sources. Coloration Technology, 127(2), 75-87.

Manjia, M. B., Abanda, F.H. \& Pettang, C. (2015). Household energy appliances in Cameroon, Environmental Management and Sustainable Development, 4(1), 73-84, 2015.

Martínez-Montejo, S. A., \& Sheinbaum-Pardo, C. (2016). The impact of energy efficiency standards on residential electricity consumption in Mexico. Energy for Sustainable Development, 32, 50-61. doi: http://dx.doi.org/10.1016/j.esd.2016.02.010

Menanteau, P. \& Lefebvre, H. (2000). Competing technologies and the diffusion of innovations: the emergence of energy-efficient lamps in the residential sector. Research Policy 29(3), 375-389.

Mills, B., \& Schleich, J. (2012). Residential energy-efficient technology adoption, energy conservation, knowledge, and attitudes: An analysis of European countries. Energy Policy, 49, 616-628.

Min, G. F., Mills, E., \& Zhang, Q. (1997). Energy efficient lighting in China: Problems and prospects. Energy Policy, 25(1), 77-83.

Min, J., Azevedo, I. L., Michalek, J., \& de Bruin, W. B. (2014). Labeling energy cost on light bulbs lowers implicit discount rates. Ecological Economics, 97, 42-50.

Nejat, P., Jomehzadeh, F., Taheri, M. M., Gohari, M., \& Abd. Majid, M. Z. (2015). A global review of energy consumption, $\mathrm{CO} 2$ emissions and policy in the residential sector (with an overview of the top ten $\mathrm{CO} 2$ emitting countries). Renewable and Sustainable Energy Reviews, 43, 843-862. 
Nfah, E. M. \& Ngundam, J. M. (2009). Feasibility of pico-hydro and photovoltaic hybrid power systems for remote villages in Cameroon. Renewable Energy, 34(6), 14451450

Nallamothu, B. K., Selvam, C., Srinivas, K., \& Prabhakaran, S. (2015). Study on energy savings by using efficient utilites in buildings. Paper presented at the 2015 Communication, Control and Intelligent Systems (CCIS).

Ouyang, J., \& Hokao, K. (2009). Energy-saving potential by improving occupants' behavior in urban residential sector in Hangzhou City, China. Energy and Buildings, 41(7), 711-720. doi: http://dx.doi.org/10.1016/j.enbuild.2009.02.003

Pode, R. (2010). Solution to enhance the acceptability of solar-powered LED lighting technology. Renewable and Sustainable Energy Reviews, 14(3), 1096-1103.

Principi, P., \& Fioretti, R. (2014). A comparative life cycle assessment of luminaires for general lighting for the office - compact fluorescent (CFL) vs Light Emitting Diode (LED) - a case study. Journal of Cleaner Production, 83, 96-107.

Raatikainen, M., Skön, J.-P., Leiviskä, K., \& Kolehmainen, M. (2016). Intelligent analysis of energy consumption in school buildings. Applied Energy, 165, 416-429.

Richardson, I., Thomson, M., Infield, D., \& Delahunty, A. (2009). Domestic lighting: A highresolution energy demand model. Energy and Buildings, 41(7), 781-789.

Schanda, J. (2005). Light emitting diodes. In R. D. Guenther (Ed.), Encyclopedia of Modern Optics (pp. 522-526). Oxford: Elsevier.

Sebitosi, A. B., \& Pillay, P. (2007). New technologies for rural lighting in developing countries: White LEDs. IEEE Transactions on Energy Conversion, 22(3), 674-679.

SIE-Cameroon, (2012). Situation energetique du Cameroun Rapport 2011. Ministere de l'eau et d'energie, Yaounde, Cameroun.

Silveira, G. T., \& Chang, S.-Y. (2011). Fluorescent lamp recycling initiatives in the United States and a recycling proposal based on extended producer responsibility and product stewardship concepts. Waste management \& research, 29(6), 656-668.

Stephan, A., \& Stephan, L. (2016). Life cycle energy and cost analysis of embodied, operational and user-transport energy reduction measures for residential buildings. Applied Energy, 161, 445-464.

UNEP. (2012). Regional report on efficient lighting in Sub-Saharan African Countries. Retrieved from: http://www.enlighten-initiative.org/portals/0/documents/countrysupport/en.lighten_Sub-Saharan\%20Report.pdf

United Nations. (2015). World population prospects. Department of Economic and Social Affairs, Population Division. Retrieved from: http://esa.un.org/unpd/wpp/Publications/Files/Key_Findings_WPP_2015.pdf

Ürge-Vorsatz, D., Petrichenko K., Staniec, M. \& Eom J. (2013). Energy use in buildings in a long-term perspective. Current Opinion in Environmental Sustainability, 5(2), 141151 
Wada, K. Akimoto, K., Sano, F., Oda, J., \& Homma, T. (2012). Energy efficiency opportunities in the residential sector and their feasibility. Energy 48(1), 5-10.

Wen, Y.-J., \& Agogino, A. M. (2008). Wireless networked lighting systems for optimizing energy savings and user satisfaction. Paper presented at the Wireless Hive Networks Conference, Austin, Texas, USA.

Zhou, H., \& Bukenya, J. O. (2016). Information inefficiency and willingness-to-pay for energy-efficient technology: A stated preference approach for China Energy Label. Energy Policy, 91, 12-21.

Zografakis, N., Karyotakis, K., \& Tsagarakis, K. P. (2012). Implementation conditions for energy saving technologies and practices in office buildings: Part 1. Lighting. Renewable and Sustainable Energy Reviews, 16(6), 4165-4174. doi: http://dx.doi.org/10.1016/j.rser.2012.03.005

Zuo, J., \& Zhao, Z. Y. (2014). Green building research—current status and future agenda: a review. Renewable and Sustainable Energy Review, 30, 271-281 
873 Appendix I: Economic analysis of efficient lighting (CFL for T2 building 874 class), uploaded in Github (2017)

\begin{tabular}{|l|l|l|l|l|l|l|l|l|}
\hline Year & CP & OC & TC & DC & TB & DB & NCF & NPV \\
\hline 0 & 59.64 & & 59.64 & 59.64 & 0 & 0 & -59.64 & -59.64 \\
\hline 1 & & 7.88 & 7.88 & 7.51 & 39.42 & 37.54 & 31.54 & 30.03 \\
\hline 2 & & 7.88 & 7.88 & 7.15 & 39.42 & 35.76 & 31.54 & 28.60 \\
\hline 3 & & 7.88 & 7.88 & 6.81 & 39.42 & 34.05 & 31.54 & 27.24 \\
\hline 4 & & 7.88 & 7.88 & 6.49 & 39.42 & 32.43 & 31.54 & 25.94 \\
\hline 5 & & 7.88 & 7.88 & 6.18 & 39.42 & 30.89 & 31.54 & 24.71 \\
\hline 6 & & 7.88 & 7.88 & 5.88 & 39.42 & 29.42 & 31.54 & 23.53 \\
\hline 7 & & 7.88 & 7.88 & 5.60 & 39.42 & 28.02 & 31.54 & 22.41 \\
\hline 8 & & 7.88 & 7.88 & 5.34 & 39.42 & 26.68 & 31.54 & 21.34 \\
\hline 9 & & 7.88 & 7.88 & 5.08 & 39.42 & 25.41 & 31.54 & 20.33 \\
\hline 10 & & 7.88 & 7.88 & 4.84 & 39.42 & 24.20 & 31.54 & 19.36 \\
\hline 11 & & 7.88 & 7.88 & 4.61 & 39.42 & 23.05 & 31.54 & 18.44 \\
\hline 12 & & 7.88 & 7.88 & 4.39 & 39.42 & 21.95 & 31.54 & 17.56 \\
\hline 13 & & 7.88 & 7.88 & 4.18 & 39.42 & 20.91 & 31.54 & 16.72 \\
\hline 14 & & 7.88 & 7.88 & 3.98 & 39.42 & 19.91 & 31.54 & 15.93 \\
\hline 15 & & 7.88 & 7.88 & 3.79 & 39.42 & 18.96 & 31.54 & 15.17 \\
\hline 16 & & 7.88 & 7.88 & 3.61 & 39.42 & 18.06 & 31.54 & 14.45 \\
\hline 17 & & 7.88 & 7.88 & 3.44 & 39.42 & 17.20 & 31.54 & 13.76 \\
\hline 18 & & 7.88 & 7.88 & 3.28 & 39.42 & 16.38 & 31.54 & 13.10 \\
\hline 19 & & 7.88 & 7.88 & 3.12 & 39.42 & 15.60 & 31.54 & 12.48 \\
\hline 20 & & 7.88 & 7.88 & 2.97 & 39.42 & 14.86 & 31.54 & 11.89 \\
\hline 21 & & 7.88 & 7.88 & 2.83 & 39.42 & 14.15 & 31.54 & 11.32 \\
\hline 22 & & 7.88 & 7.88 & 2.70 & 39.42 & 13.48 & 31.54 & 10.78 \\
\hline Total & $\mathbf{5 9 . 6 4}$ & $\mathbf{1 7 3 . 4 5}$ & $\mathbf{2 3 3 . 0 9}$ & $\mathbf{1 6 3 . 4}$ & $\mathbf{8 6 7 . 2}$ & $\mathbf{5 1 8 . 8 9}$ & $\mathbf{6 3 4 . 1}$ & $\mathbf{3 5 5 . 4 7}$ \\
\hline NPV & & & & $\mathbf{2}$ & $\mathbf{4}$ & & $\mathbf{5}$ & \\
\hline BCR (Total DB/Total DC) & & & & & $\mathbf{3 3 8 . 5 4}$ \\
\hline & & & & & & & & $\mathbf{3 . 1 8}$ \\
\hline 19 & & & & & & & \\
\hline 19 & & & & & & & & \\
\hline
\end{tabular}

875

876 Where:

877 CP: capital cost

878 OC: operation cost

879 TC: total cost

880 DC: discounted cost

881 DB: discounted benefit

882 NCF: net cash flow

883 NPV: net present value

'ADI; activity data for incandescent lamp

ii ADCFL; activity data for CFL 